\title{
PERBEDAAN DAYA HAMBAT ANTIBAKTERI ANTARA EKSTRAK DAUN SIRIH \\ MERAH (Piper crocatum) DAN EKSTRAK DAUN SIRIH HIJAU \\ (Piper betle L.) TERHADAP BAKTERI Streptococcus mutans (STUDY EKSPERIMENTAL LAB DI LABORATORIUM MIKROBIOLOGI FAKULTAS FARMASI UMI 2016)
}

\author{
Risnayanti Anas, Kurniawan, Yustisia puspitasari \\ Fakultas kedokteran Gigi Universitas Muslim Indonesia, Makassar \\ Email: risnayanti.anas@gmail.com
}

\begin{abstract}
Background: Red Betel (Piper crocatum) and green betel (Piper betle L.) is believed to have efficacy preventing dental caries disease caused by the bacterium Streptococcus mutans. Purpose: Research purpose is to review describes different inhibitory extract of red betel leaf and leaf green betel Against bacteria Streptococcus mutans. Materials and Methods: Operations Research is an experimental by design post test only group design. Sample Research : is a pure culture of Streptococcus mutans bacteria in the laboratory of Microbiology, Faculty of Pharmacy, University Muslim Indonesia. Analitical statistics to be done using One Way ANOVA. Furthermore, the Post Hoc multiple comparison test for review red betel Differences And green betel inhibit bacteria. Results: Based on the statistical test showed that the zone of inhibition power of 4 Different the concentration $(0.1 \%, 1 \%, 10 \%, 100 \%)$ As well as having a significant difference between the two TYPE betel leaf against bacteria Streptococcus mutans. Conclusion: The findings of the data analysis can be concluded that the green betel leaf showed inhibitory better than red betel leaf against bacteria Streptococcus mutans.
\end{abstract}

Key words: Red betel leaf (Piper crocatum), Green Betel leaf (Piper betle L.) Streptococcus mutans.

\section{PENDAHULUAN}

Karies merupakan suatu penyakit pada jaringan keras gigi, yaitu email, dentin dan sementum yang disebabkan aktivitas jasad renik yang ada dalam suatu karbohidrat yang diragikan. Bakteri yang paling dominan adalah bakteri Streptococcus mutans. Streptococcus mutans merupakan salah satu bakteri gram positif patogen penyebab karies yang ditadai dengan adanya demineralisasi pada gigi. ${ }^{1}$

Kini telah banyak dilakukan penelitian dengan memanfaatkan bahan alam yang kesemuanya bertujuan untuk menghasilkan obatobatan dalam upaya mendukung program pelayanan kesehatan gigi, 
Perbedaan daya hambat antibakteri antara ekstrak daun sirih merah dan ekstrak daun sirih hijau terhadap bakteri Streptococcus mutans

khususnya untuk mencegah karies gigi. $^{2}$

Pemanfaatan bahan alam sebagai obat di Indonesia akhir-akhir ini meningkat, seperti bunga cengkeh, air kelopak bunga rosella dan daun sirih. Bahkan beberapa bahan alam telah diproduksi secara fabrikasi dalam skala besar. Penggunaan obat tradisional dinilai memiliki efek samping lebih kecil dibandingkan dengan obat yang berasal dari bahan kimia, disamping itu harganya lebih terjangkau. ${ }^{3}$

Penelitian tentang sirih juga telah banyak dilakukan karena sirih banyak ditemui di Indonesia sebagai tanaman obat-obatan. Hal ini dikarenakan sirih memiliki sifat antibakteri, dan antijamur sehingga komponen tersebut dibutuhkan untuk menghambat aktivitas bakteri. Adapun jenisnya yaitu sirih hijau, sirih merah, sirih hitam, sirih kuning dan sirih perak. $^{4}$

Secara umum daun sirih mengandung minyak atsiri, senyawa fenol propanoid, dan tannin. Senyawa ini bersifat antibakteri dan antijamur yang kuat dan dapat menghambat pertumbuhan beberapa jenis bakteri. ${ }^{4}$

Penggunaan daun sirih merah sebagai daya hambat terhadap

Streotococcus mutans telah diuji dan telah menunjukkan hasil yang baik. Diketahui bahwa hasil Ekstrak daun sirih merah mempunyai kemampuan dalam menghambat pertumbuhan Streptococcus mutans. Daya hambat ekstrak daun sirih merah dengan konsentrasi $100 \%$, memiliki keefektifan yang sama dengan Chlorhexidine (sebagai kontrol positif). Konsentrasi minimal pada ekstrak daun sirih merah dalam menghambat Streptococcus mutans adalah $1 \%{ }^{5}$

Adapun penlitian tentang ekstrak daun sirih hijau (Piper Betle L.) terhadap bakteri Streptococcus mutans atau S. mutans menunjukkan hasil yang baik. Hasilnya yaitu pertama terdapat efektivitas antibakteri dari ekstrak daun sirih hijau terhadap pertumbuhan $S$. mutans, kedua terdapat perbedan efektivitas antara 20 konsentrasi ekstrak daun sirih hijau terhadap pertumbuhan $S$. mutans, ketiga konsentrasi efektif dari ekstrak daun sirih hijau terhadap pertumbuhan S. mutans dari penelitian ini adalah pada konsentrasi $20 \%$, keempat kadar hambat minimum dari ekstrak daun sirih hijau terhadap pertumbuhan $S$. mutans adalah pada konsentrasi $1 \%{ }^{6}$

Streptococcus

mutans

merupakan bakteri gram positif 
Perbedaan daya hambat antibakteri antara ekstrak daun sirih merah dan ekstrak daun sirih hijau terhadap bakteri Streptococcus mutans

berbentuk bulat yang khas membentuk pasangan atau rantai selama masa pertumbuhannya. Streptococcus merupakan salah satu golongan bakteri yang heterogen. Beberapa diantaranya merupakan anggota flora normal pada manusia. Streptococcus mutans merupakan bakteri gram positf $(+)$, bersifat non motil (tidak bergerak), berdiameter 1-2 $\mu \mathrm{m}$, bakteri anaerob fakultatif. Memiliki bentuk bulat atau bulat telur, tersusun seperti rantai dan tidak membentuk spora. ${ }^{2}$

\section{Streptococcus}

memproduksi

mutans

glucosyltransferase (GTF), sehingga bakteri ini dapat membentuk koloni yang melekat dengan erat pada permukaan gigi. Streptococcus mutans juga menghasilkan polisakarida ekstraseluler lengket dari karbohidrat makanan dan

mampu mempermentasikan karbohindrat menjadi asam, sehingga asam tersebut melarutkan email gigi. ${ }^{7}$

Berdasarkan uraian diatas, maka perlu dilakukan penelitian ini tentang perbedaan daya hambat daun sirih merah (Piper crocatum) dan daun sirih hijau (Piper betle L.) terhadap pertumbuhan bakteri Streptococcus mutans dengan menggunakan metode ekstraksi sederhana (maserasi) dan dengan penggunaan kadar etanol yang lebih tinggi, 96\% untuk melihat ada tidaknya perbedaan.

\section{METODE PENELITIAN}

Penelitian ini bersifat eksperimental post test only control group design. Populasi adalah dua jenis daun sirih yang digunakan. Sampel adalah daun sirih merah (Piper crocatum) dan daun sirih hijau (Piper betle L.). Sampel diambil dengan menggunakan metode Purposive Sampling, kemudian data penelitian dilakukan uji normalitas dengan Shapiro Wilk dan uji homogenitas dengan Levene Test, kemudian dianalisis dengan uji One Way Anova untuk melihat perbedaan antar kelompok kemudian dilanjutkan dengan uji Tukey HSD. Untuk menentukan ekstrak daun sirih merah dan daun sirih hijau dengan konsentrasi $0,1 \%, 1 \%, 10 \%$, dan $100 \%$ berdasarkan rumus Lukito $4 n \geq 20: n \geq$ $5=5 . n=$ jumlah pengulangan. $P=$ jumlah perlakuan atau konsentrasi. 
Perbedaan daya hambat antibakteri antara ekstrak daun sirih merah dan ekstrak daun sirih hijau terhadap bakteri Streptococcus mutans

\section{HASIL PENELITIAN}

Tabel 1. Daya hambat ekstrak daun sirih merah terhadap bakteri Streptococcus mutans.

\begin{tabular}{|c|c|c|c|c|c|c|}
\hline \multirow{3}{*}{ Replikasi } & \multirow{2}{*}{\multicolumn{2}{|c|}{$\begin{array}{l}\text { Kontrol } \\
(\mathrm{mm})\end{array}$}} & \multirow{2}{*}{\multicolumn{2}{|c|}{$\begin{array}{l}\text { Konsentrasi } \\
(\mathrm{mm})\end{array}$}} & \multirow[b]{3}{*}{$1 \%$} & \multirow[b]{3}{*}{$0,1 \%$} \\
\hline & & & & & & \\
\hline & $\mathbf{K}+$ & K- & $100 \%$ & $10 \%$ & & \\
\hline 1. & 20,73 & 0 & 23,06 & 14,97 & 9,21 & 8,25 \\
\hline 2. & 20,82 & 0 & 32,44 & 14,22 & 10,84 & 9,45 \\
\hline 3. & 20,24 & 0 & 27,72 & 13,28 & 11,33 & 9,04 \\
\hline 4. & 20,05 & 0 & 21,74 & 11,78 & 11,78 & 10,27 \\
\hline 5. & 20,32 & 0 & 29,02 & 13,96 & 12,49 & 12,49 \\
\hline Rata-rata & 20,432 & 0 & 26,796 & 13,642 & 10,59 & 9,9 \\
\hline Std Deviasi & 20,43 & 0 & 4,39 & 1,20 & 1,45 & 1,63 \\
\hline
\end{tabular}

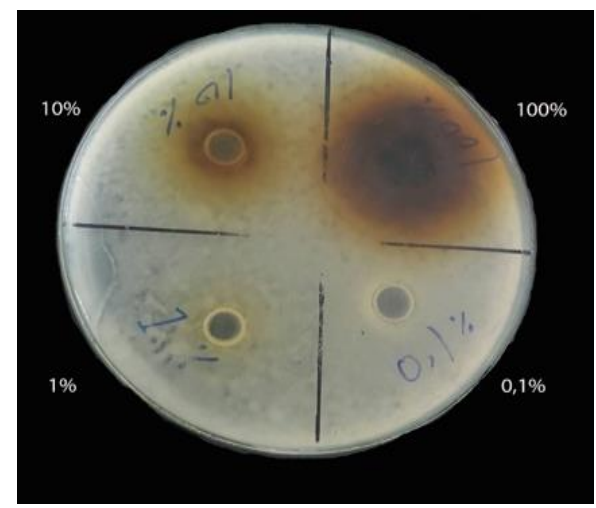

Gambar 1. Ekstrak daun sirih merah terhadap pertumbuhan Streptococcus mutans.

Tabel 2. Daya Hambat Ekstrak daun sirih hijau terhadap bakteri Streptococcus mutans

\begin{tabular}{|c|c|c|c|c|c|c|}
\hline \multirow[t]{2}{*}{ Replikasi } & \multicolumn{2}{|l|}{$\begin{array}{l}\text { Kontrol } \\
(\mathrm{mm})\end{array}$} & \multicolumn{2}{|c|}{$\begin{array}{l}\text { Konsentrasi } \\
(\mathrm{mm})\end{array}$} & \multirow[b]{2}{*}{$1 \%$} & \multirow[b]{2}{*}{$0,1 \%$} \\
\hline & $\mathbf{K}+$ & $\mathrm{K}-$ & $100 \%$ & $10 \%$ & & \\
\hline 1. & 20,73 & 0 & 27,62 & 19,37 & 18,60 & 15,17 \\
\hline 2. & 20,82 & 0 & 31,72 & 23,89 & 19,64 & 11,61 \\
\hline 3. & 20,24 & 0 & 31,77 & 23,89 & 18,10 & 12,69 \\
\hline 4. & 20,05 & 0 & 31,01 & 28,27 & 17,74 & 15,80 \\
\hline 5. & 20,32 & 0 & 32,67 & 24,70 & 18,25 & 10,13 \\
\hline Rata-rata & 20,432 & 0 & 30,958 & 24,024 & 18,466 & 13,08 \\
\hline Std. Deviasi & 20,43 & 0 & 1,95 & 3,16 & 0,72 & 2,38 \\
\hline
\end{tabular}

Uji normalitas pada data ekstrak daun sirih hijau (Piper betle L.) didapatkan nilai $p>0,05$ sehingga dapat disimpulkan bahwa data terdistribusi normal.

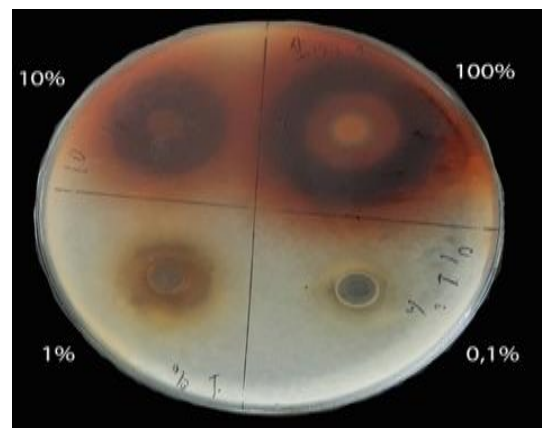

Gambar 2 Ekstrak daun sirih hijau terhadap pertumbuhan Streptococcus mutans.

Tabel 3 Perbedaan daya hambat ekstrak daun sirih merah dan ekstrak daun sirih hijau terhadap bakteri Streptococcus mutans

\begin{tabular}{lccc}
\hline \multicolumn{1}{c}{ Kelompok } & $\begin{array}{c}\text { Mean } \\
\text { Difference }\end{array}$ & Std. Eror & P Value \\
& & & \\
\hline Sirih merah 0,1\% - Sirih hijau 0,1\% & $-3,2600$ & 1,51049 & 0,402 \\
Sirih merah 1\%-Sirih hijau 1\% & $-7,8720$ & 1,51049 & 0,000 \\
Sirih merah 10\% - Sirih hijau 10\% & $-10,3820$ & 1,51049 & 0,000 \\
Sirih merah 100\% - Sirih hijau 100\% & $-4,16200$ & 1,51049 & 0,143 \\
\hline & & &
\end{tabular}

\section{PEMBAHASAN}

Pada penelitian ini data dianalisis, kemudian dilakukan uji normalitas dengan uji Shapiro-Wilk dan uji homogenitas dengan Levene Test. Kemudian data tersebut dianalisis dengan uji one way anova untuk mengetahui adanya perbedaan antar kelompok kemudian dilanjutkan dengan uji Tukey HSD untuk mengetahui besarnya perbedaan antar kelompok.

Pada uji daya hambat yang dilakukan terdapat 4 konsentrasi ekstrak daun sirih merah dan ekstrak daun sirih hijau yang berbeda yaitu 
Perbedaan daya hambat antibakteri antara ekstrak daun sirih merah dan ekstrak daun sirih hijau terhadap bakteri Streptococcus mutans

$0,1 \%, 1 \%, 10 \%$, dan $100 \%$ dengan masing - masing replikasi sebanyak 5 kali, hal ini dilakukan untuk mengetahui daya hambat masing-masing konsentrasi terhadap pertumbuhan bakteri Streptococcus mutans.

Berdasarkan hasil penelitian diperoleh bahwa ekstrak daun sirih merah pada konsentrasi $0,1 \%, 1 \%$, $10 \%$ dan $100 \%$ mempunyai daya hambat terhadap bakteri Streptococcus mutans. Rata-ratanya pada konsentrasi 0,1\% (9,9 mm), 1\% (10,59 mm), 10\% $(13,64 \mathrm{~mm})$, dan $100 \%(26,79 \mathrm{~mm})$. Pada konsentrasi tersebut dibandingkan dengan kontrol positif (Chlorexidine 0,2\%), ekstrak daun sirih merah pada konsentrasi $100 \%$ sudah lebih baik dibandingkan kontrol positif. Hal ini sesuai dengan yang hasil penelitian yang dilakukan oleh Ningsi (2013) mengatakan ekstrak daun sirih pada konsentrasi $1 \%, 10 \%$, dan $100 \%$ mempunyai efek antibakteri terhadap Streptococcus mutans. ${ }^{5}$

hasil penelitian pada ekstrak daun sirih hijau pada konsentrasi $0,1 \%$, $1 \%, 10 \%$ dan $100 \%$ mempunyai daya hambat terhadap bakteri Streptococcus mutans. Rata-ratanya pada konsentrasi 0,1\% (13,08 mm), $1 \%$ (18,46 mm), $10 \%$ $(24,02 \mathrm{~mm})$, dan $100 \%(30,95 \mathrm{~mm})$. Pada konsentrasi tersebut dibandingkan dengan kontrol positif (Chlorexidine 0,2\%), ekstrak daun sirih hijau pada konsentrasi $10 \%$ dan $100 \%$ sudah lebih baik dibandingkan kontrol positif. Hal ini sesuai dengan penelitian yang dilakukan Mita (2011) mengatakan bahwa ekstrak daun sirih hijau mempunyai efek antibakteri terhadap Streptococcus mutans. ${ }^{6}$

Hasil dari perbedaan antara ekstrak daun sirih merah dan ekstrak daun sirih hijau pada konsentrasinya $0,1 \%$ ekstrak daun sirih hijau lebih besar diameternya sekitar $(3,26 \mathrm{~mm}) \mathrm{di}$ bandingkan ekstrak daun sirih merah, konsentrasi $1 \%$ ekstrak daun sirih hijau lebih besar diameternya sekitar $(7,87$ $\mathrm{mm}$ ) di bandingkan ekstrak daun sirih merah, konsentrasi 10\% ekstrak daun sirih hijau lebih besar diameternya sekitar $(10,38 \mathrm{~mm})$ di bandingkan ekstrak daun sirih merah, konsentrasi $100 \%$ ekstrak daun sirih hijau lebih besar diameternya sekitar $(4,16 \mathrm{~mm}) \mathrm{di}$ bandingkan ekstrak daun sirih merah.

\section{KESIMPULAN}

Ekstrak daun sirih merah dan ekstrak daun sirih hijau efektif menghambat bakteri Streptococcus mutans. Ekstrak dau sirih merah pada konsentrasi $100 \%$ lebih efektif dibandingkan kontor positif (Chorexidine 0,2\%), ekstrak daun sirih 
Perbedaan daya hambat antibakteri antara ekstrak daun sirih merah dan ekstrak daun sirih hijau terhadap bakteri Streptococcus mutans

hijau pada konsentrasi $10 \%$ dan $100 \%$ lebih efektif dibandingkan kontrol positif (Chorexidine 0,2\%).

Dari kedua jenis ekstrak daun sirih yang digunakan dalam penelitian ini, ekstrak daun sirih hijau (Piper betle L.) memiliki efek daya hambat yang lebih baik terhadap pertumbuhan bakteri Streptococcus mutans dibandingkan ekstrak daun sirih merah (Piper crocatum).

\section{DAFTAR PUSTAKA}

1. Riswandy A, Apriyanto D, Budiarti LY. Aktivitas Antibakteri Ekstrak Air Kelopak Bunga Rosella (Hibiscus Sabdariffa L.) Terhadap Pertumbuhan Streptococcus Mutans In Vitro. Jurnal Kedokteran Gigi Dentino, 2014;2(1).

2. Andries JR, Gunawan PN, Supit A. Uji Efektivitas AntiBakteri Ekstrak Bunga Cengkeh Terhadap Bakteri Streptococcus mutans Secara In vitro. Jurnal e-Gigi(eG),2014:2(2).
3. Noventi W, Carolia N. Potensi Ekstrak Daun Sirih Hijau (Piper Betle L.) Sebagai Alternatif Terapi Acne Vulgaris. Jurnal Fakultas Kedokteran. Universitas Lampung, 2016.

4. Nisa GK, Nugroho WA, Hendrawa Y. Ekstraksi Daun Sirih Merah (Piper Crocatum) dengan Metode Microwave Assisted Extraction (MAE). Jurnal Biopreses Komoditas Tropis, . 2014;2(1).

5. Ningsih QIW, Lestari PE, Sulistyani E. Daya Hambat Ekstrak Daun Sirih Merah (Piper Crocatum) terhadap Streptococcus Mutans. Jurnal Fakultas Kedokteran Gigi. Universitas Jember, 2013.

6. Afrilla MS. Efektivitas Ekstrak Daun Sirih Hijau Terhadap Pertumbuhan Streptococcus Mutans (In Vitro). (Skripsi). Medan: Universitas Sumatera Utara, 2011.

7. Rifdayani N, Budiarti LY, Carabelly AN. Perbandingan Efek Bakterisidal Ekstrak Mengkudu (Morinda Cirifolia Liin) $100 \%$ da Povidone lodine 1\% Terhadap Streptococcus Mutans In Vitro. Jurnal Kedokteran Gigi Dentino, 2014;2(1). 